\title{
Hypothermia for aortic surgery
}

\author{
Randall B. Griepp, MD, and Gabriele Di Luozzo, MD
}

\begin{abstract}
Hypothermic circulatory arrest has been used during aortic arch repairs with acceptable neurologic outcomes. Through the years, we have studied the effects of deep hypothermia on brain metabolism and perfusion both in a pig model and in surgical patients. Hypothermic circulatory arrest has also been used as a method of organ protection in the repair of thoracoabdominal aortic aneurysms. We summarize the clinical and laboratory studies to support the routine use of hypothermic circulatory arrest in clinical practice. (J Thorac Cardiovasc Surg 2013;145:S56-8)
\end{abstract}

Hypothermic circulatory arrest (HCA) was first conceptualized by Bigelow and colleagues ${ }^{1}$ in 1950 , and was applied as a strategy for correction of congenital heart defects by Lewis and Taufic ${ }^{2}$ in 1953 and by Drew and associates ${ }^{3}$ in 1959. It was first applied to a series of aortic surgical patients in $1975 .{ }^{4}$ Since then, HCA has been used in practically all aspects of aortic surgery, most frequently in surgery of the aortic arch and thoracoabdominal aorta. We will discuss the physiologic underpinnings of HCA and its utility, limitations, and implementation. The physiologic basis for preservation of tissue integrity during a period of interrupted circulation by hypothermia relies on a lowering of metabolic rate by reduction of temperature, which allows the lengthening of an intrinsic tolerance for ischemia.

\section{BRAIN PROTECTION (AORTIC ARCH SURGERY)}

In the experimental animal, cerebral metabolic rate can be determined by measuring arterial oxygen content and cerebral mixed venous content (sampled from the sagittal sinus) and ascertaining cerebral blood flow with microspheres labeled with radioactive isotopes or fluorescent dye. Temperature is varied by means of cardiopulmonary bypass. One can then plot cerebral metabolic rate for oxygen as a function of temperature. In a series of experiments conducted in pigs, we ascertained that the relationship appeared to be exponential (linear in a semilogarithmic plot) with a ratio of metabolic rates at 2 temperatures $10^{\circ} \mathrm{C}$ apart (Q10) of 2.2..$^{5}$ A similar relationship has been shown in the work of others. ${ }^{6}$

In human beings, determining the Q10 - the relationship between temperature and cerebral metabolic rate-is

\footnotetext{
From the Department of Cardiothoracic Surgery, Mount Sinai School of Medicine, New York, NY.

Disclosures: Drs Griepp and Di Luozzo have nothing to disclose with regard to commercial support.

Read at The American Association for Thoracic Surgery Aortic Symposium, New York, New York, April 26-27, 2012.

Received for publication May 21, 2012; revisions received Oct 16, 2012; accepted for publication Nov 28, 2012.

Address for reprints: Randall B. Griepp, MD, Cardiothoracic Surgery, Mount Sinai School of Medicine, One Gustav Levy Place, New York, NY 10029 (E-mail: randall.griepp@mountsinai.org).

$0022-5223 / \$ 36.00$

Copyright (C) 2013 by The American Association for Thoracic Surgery

http://dx.doi.org/10.1016/j.jtcvs.2012.11.072
}

somewhat more challenging. We nevertheless carried out a series of measurements in 37 adult patients undergoing surgery requiring HCA. Arterial oxygen content was easily determined, and mixed cerebral venous oxygen content was estimated from samples from the jugular bulb. A relative cerebral blood flow was approximated with an ultrasonic flow probe used on the left common carotid artery. By thus estimating cerebral metabolic rate at several temperatures, it was possible to calculate the Q10 for each individual; the average value was 2.3 , very close to the number obtained in the experimental laboratory. ${ }^{7}$

If one accepts the clinical observation that recovery of normal brain function is possible with interruption of cerebral blood flow for less than 5 minutes at normothermia (baseline ischemic tolerance) and that Q10 is 2.3, Table 1 can be constructed, defining safe intervals for HCA at various temperatures. Although 1 hour of HCA at profoundly hypothermic levels $\left(10^{\circ} \mathrm{C}-15^{\circ} \mathrm{C}\right)$ seemed safe in our initial clinical experience as well as that of others, ${ }^{8}$ we have subsequently become convinced on the basis of several observations that the 30 minutes of safe HCA at these temperatures predicted by the Q10 calculation is actually correct. It was noted relatively soon that patients had a significantly higher incidence of temporary neurologic dysfunction-delayed awakening, postoperative confusion, and agitation - when HCA durations exceeded 25 minutes. ${ }^{9}$ This led to rigorous studies involving preoperative and postoperative testing of cognitive function, which revealed reductions in memory and fine motor control several weeks postoperatively after durations of HCA longer than 25 minutes. ${ }^{9}$ No such reduction in cognitive function was seen in patients undergoing cardiopulmonary bypass without HCA or with HCA durations of less than 25 minutes. ${ }^{10}$ Subsequently, intraoperative observations with near-infrared spectroscopy established that absolute saturations in the brain fall to about $60 \%$ after 30 minutes of $\mathrm{HCA}$ at $15^{\circ} \mathrm{C}$ and that patients with increasing intervals of saturations below this level-inevitable with longer durations of HCA—suffer a greater number of adverse outcomes after surgery. ${ }^{11,12}$

On the basis of Q10 calculation and clinical observations during the past decade, we therefore feel quite strongly that intervals of HCA longer then those indicated here may be 
TABLE 1. Calculated safe intervals for interruption of brain perfusion at various temperatures

\begin{tabular}{lcc}
\hline Temperature & $\begin{array}{c}\text { Cerebral metabolic rate } \\
(\% \text { of baseline) }\end{array}$ & Safe duration (min) \\
\hline $37^{\circ} \mathrm{C}$ & 100 & 5 \\
$30^{\circ} \mathrm{C}$ & $56(52-60)$ & $9(8-10)$ \\
$25^{\circ} \mathrm{C}$ & $37(33-42)$ & $14(12-15)$ \\
$20^{\circ} \mathrm{C}$ & $24(21-29)$ & $21(17-24)$ \\
$15^{\circ} \mathrm{C}$ & $16(13-20)$ & $31(25-38)$ \\
$10^{\circ} \mathrm{C}$ & $11(8-14)$ & $45(36-62)$ \\
\hline
\end{tabular}

Data are means with $95 \%$ confidence intervals.

tolerable if unavoidable but are likely to result in ischemic cerebral injury.

\section{SPINAL CORD PROTECTION (SELECTIVE CEREBRAL PERFUSION AND THORACOABDOMINAL SURGERY)}

Just as brain protection is one of the most important issues in proximal aortic surgery, protection of the spinal cord to avoid paraparesis and paraplegia emerged as a major challenge as more surgeons undertook thoracoabdominal aneurysm (TAAA) repair. Our clinical experience suggested that even mild degrees of passive hypothermia increase the ischemic tolerance of the spinal cord, and in 2003 we carried out a simple set of experiments to test this in the porcine model. Through a small thoracotomy, the aorta was clamped just distal to the left subclavian artery for variable intervals: at normothermia in one set of animals and at $32^{\circ} \mathrm{C}$ in another group. After removal of the clamp, the incisions were closed and the animals were allowed to awaken. Hind limb function was observed for 7 days. The maximum interval of crossclamping associated with normal recovery at normothermia was 20 minutes; however, full recovery was seen after 50 minutes of ischemia at $32^{\circ} \mathrm{C}^{11,12}$

A calculation of Q10 that is based only on these 2 points yields a number much higher than that derived for the brain; however, clinical reports of paraplegia in patients treated with selective cerebral perfusion (SCP) at moderate hypothermia $\left(25^{\circ} \mathrm{C}-28^{\circ} \mathrm{C}\right)$ were nevertheless disturbing. In a study of SCP at $28^{\circ} \mathrm{C}$ in the laboratory, we demonstrated that there is minimal spinal cord perfusion distal to T10. Ninety minutes of SCP at $28^{\circ} \mathrm{C}$ resulted in a $60 \%$ incidence of paraplegia, and no animals recovered hind limb function after 120 minutes of SCP at this temperature. ${ }^{13}$ On the basis of these findings, as well as other laboratory and clinical studies, we assembled the table of intervals for safe spinal cord ischemia at various temperatures (Table 2). According to these numbers, it appears that the Q10 for the spinal cord is almost identical to that for the brain: 2.2. The differences in the safe ischemic intervals between brain and spinal cord are a consequence of the baseline tolerance of 20 minutes at normothermia for the spinal cord versus a brain tolerance of only 5 minutes for normothermic ischemia. An appreciation
TABLE 2. Calculated safe intervals for interruption of spinal cord perfusion at various temperatures

\begin{tabular}{lc}
\hline Temperature & Safe duration $(\mathbf{m i n})$ \\
\hline $37^{\circ} \mathrm{C}$ & 20 \\
$32^{\circ} \mathrm{C}$ & 50 \\
$28^{\circ} \mathrm{C}$ & 75 \\
$20^{\circ} \mathrm{C}$ & 120 \\
\hline
\end{tabular}

of the safe ischemic intervals for the spinal cord is clearly important for operating on the thoracoabdominal aorta as well as in using SCP for proximal aortic surgery.

\section{Thoracoabdominal Surgery}

The use of deep HCA has been advocated for operations of the descending and thoracoabdominal aorta for many years. Impressive series of extensive thoracoabdominal resections have been reported by both Kulik and colleagues ${ }^{14}$ and Fehrenbacher and coworkers ${ }^{15}$ with deep HCA, with low rates of mortality, stroke, and paraplegia. We have reviewed our own recent experience of extensive TAAA repair, and among 262 cases found 90 suitable for a propensity-matched study to compare HCA with non-HCA management. ${ }^{16}$ The results show a lesser overall incidence of reversible visceral complications in the HCA group: a lower rate of acute renal failure and need for temporary dialysis and a lower rate of reversible liver damage. The overall analysis documents a greater risk of visceral complications with prolonged operations-and therefore prolonged distal ischemia-in cases of protection with mild rather than deep hypothermia.

\section{Ischemic Tolerance of Abdominal Viscera}

According to laboratory and clinical observations, the kidneys are more sensitive to ischemia than the liver or the bowel, and none of these organs are as vulnerable to ischemic damage as the spinal cord. At $28^{\circ} \mathrm{C}$ in pigs, some visceral injury occurs by 90 minutes, and lethal injury is likely after 120 minutes. ${ }^{17}$ In human beings, even severe visceral ischemic damage can often be managed (eg, acute renal failure), although some damage (eg, extensive bowel infarction) may be incompatible with survival.

\section{Bleeding Complications With Deep Hypothermia}

Despite better results with deep rather than moderate hypothermia with SCP and in extensive TAAA, there has been a reluctance to adopt deep hypothermia, largely because of a perception that there is a vastly increased risk of bleeding complications with lower temperatures. Although direct comparisons are fraught with all the limitations associated with comparing operations in different institutions, a survey of several series of arch replacements reported by different groups in 2007 demonstrates no tendency for lower temperature SCP to be associated with increased bleeding complications. ${ }^{18-22}$ In our own recent series of TAAA operations, 
only platelet transfusions were higher in the patients with deep hypothermia, and in the propensity-matched cohort there was no difference between the mild and deep hypothermia groups in transfusions of red blood cells, freshfrozen plasma, or platelets. ${ }^{17}$

\section{IMPLEMENTATION OF HCA}

After many years of laboratory experiments and clinical studies, we have become convinced that the utility of deep hypothermia for aortic surgery outweighs its chief disadvantage: that it takes extra time. We have developed respect for the limitations of HCA and support the importance of strict guidelines for its safe implementation. For optimal cooling of the brain, the blood temperature should not be more than $10^{\circ} \mathrm{C}$ lower than the esophageal temperature; a minimum of 30 minutes is required, and thorough cooling should be assured by a jugular venous saturation greater than $95 \%$ or a cerebral tissue oxygen saturation greater than $85 \%$ by near-infrared spectroscopy. The head should be packed in ice to guard against upward drift of the temperature during the arrest interval. The safe duration of HCA should be based on the Q10 and on intraoperative monitoring with near-infrared spectroscopy. In cases in which the safe ischemic interval is approached or surpassed, rewarming should be preceded by a 5-minute interval of cold reperfusion, which has been associated with improved cognitive recovery in experimental studies. ${ }^{23}$ With the blood no more than $10^{\circ} \mathrm{C}$ warmer than the esophageal temperature and never above $36.5^{\circ} \mathrm{C}$, rewarming should then begin. Warming should be stopped when the esophageal temperature reaches $35^{\circ} \mathrm{C}$ and the bladder temperature reaches $32^{\circ} \mathrm{C}$. Partial bypass-pulsatile perfusion-can be helpful in speeding perfusion during the final stages of rewarming.

\section{CONCLUSIONS}

Hypothermia is by far the most effective modality for preservation of tissue integrity during unavoidable periods of interrupted blood flow. Safe ischemic intervals as much as 6-fold longer than normothermic baselines are readily within reach of the cardiovascular surgeon. Nonetheless, a thorough understanding of the physiologic principles and limitations of HCA is required for patients and surgeons to enjoy its benefits and avoid its drawbacks.

\section{References}

1. Bigelow WG, Lindsay WK, Greenwood WF. Hypothermia; its possible role in cardiac surgery: an investigation governing survival in dogs at low body temperatures. Ann Surg. 1950;132:849-66.

2. Lewis FJ, Taufic J. Closure of atrial septal defects with the aid of hypothermia: experimental accomplishments and the report of one successful case. Surgery. 1953;33:52-9.
3. Drew CE, Keen G, Benazon DB. Profound hypothermia. Lancet. 1959;1: 745-7.

4. Griepp RB, Stinson EB, Hollingsworth JF, Buehler DJ. Prosthetic replacement of the aortic arch. J Thorac Cardiovasc Surg. 1975;70:1051-63.

5. Ehrlich MP, McCullough JN, Zhang N, Weisz DJ, Juvonen T, Bodian CA, et al. Effect of hypothermia on cerebral blood flow and metabolism in the pig. Ann Thorac Surg. 2002;73:191-7.

6. Haldenwang PL, Strauch JT, Müllem K, Reiter H, Liakopoulos O, Fischer JH, et al. Effect of pressure management during hypothermic selective cerebral perfusion on cerebral hemodynamics and metabolism in pigs. $J$ Thorac Cardiovasc Surg. 2010;139:1623-31.

7. McCullough JN, Zhang N, Reich DL, Juvonen TS, Klein JJ, Spielvogel D, et al. Cerebral metabolic suppression during hypothermic circulatory arrest in humans. Ann Thorac Surg. 1999;67:1895-9.

8. Percy A, Widman S, Rizzo JA, Tranquilli M, Elefterides JA. Deep hypothermic circulatory arrest in patients with high cognitive needs: full preservation of cognitive abilities. Ann Thorac Surg. 2009;87:117-23.

9. Ergin MA, Uysal S, Reich DL, Apaydin A, Lansman SL, McCullough JN, et al. Temporary neurological dysfunction after deep hypothermic circulatory arrest: a clinical marker of long-term functional deficit. Ann Thorac Surg. 1999;67: 1887-90; discussion 1891-4.

10. Reich DL, Uysal S, Sliwinski M, Ergin MA, Kahn RA, Konstadt SN, et al. Neuropsychologic outcome after deep hypothermic circulatory arrest in adults. J Thorac Cardiovasc Surg. 1999;117:156-63.

11. Fischer GW, Benni PB, Lin HM, Satyapriya A, Alfonso G, Di Luozzo G, et al. Mathematical model for describing cerebral oxygen desaturation in patients undergoing deep hypothermic circulatory arrest. Br J Anesth. 2010;104:59-66.

12. Fischer GW, Lin HM, Krol M, Galati MF, Di Luozzo G, Griepp RB, et al. Noninvasive cerebral oxygenation may predict outcome in patients undergoing aortic arch surgery. J Thorac Cardiovasc Surg. 2011;141:815-21.

13. Strauch JT, Lauten A, Spielvogel D, Rinke S, Zhang N, Weisz D, et al. Mild hypothermia protects the spinal cord from ischemic injury in a chronic porcine model. Eur J Cardiothorac Surg. 2004;25:708-15.

14. Kulik A, Castner CF, Kouchoukos NT. Outcomes after thoracoabdominal aortic aneurysm repair with hypothermic circulatory arrest. J Thorac Cardiovasc Surg. 2011;141:953-60.

15. Fehrenbacher JW, Siderys H, Terry C, Kuhn J, Corvera JS. Early and late results of descending thoracic and thoracoabdominal aortic aneurysm open repair with deep hypothermia and circulatory arrest. J Thorac Cardiovasc Surg. 2010;140(6 Suppl):S154-60; discussion S185-90.

16. Weiss AJ, Lin HM, Bischoff MS, Scheumann J, Lazala R, Griepp RB, et al. A propensity score-matched comparison of deep versus mild hypothermia during thoracoabdominal aortic surgery. J Thorac Cardiovasc Surg. 2012;143: 186-93.

17. Etz CD, Luehr M, Kari FA, Lin HM, Kleinman G, Zoli S, et al. Selective cerebral perfusion at $28^{\circ} \mathrm{C}$-is the spinal cord safe? Eur J Cardiothorac Surg. 2009;36: 946-55.

18. Kamiya H, Hagl C, Kropivnitskaya I, Böthig D, Kallenbach K, Khaladj N, et al. The safety of moderate hypothermic lower body circulatory arrest with selective cerebral perfusion: a propensity score analysis. J Thorac Cardiovasc Surg. 2007; 133:501-9.

19. Pacini D, Leone A, Di Marco L, Marsilli D, Sobaih F, Turci S, et al. Antegrade selective cerebral perfusion in thoracic aorta surgery: safety of moderate hypothermia. Eur J Cardiothorac Surg. 2007;31:618-22.

20. Sasaki H, Ogino H, Matsuda H, Minatoya K, Ando M, Kitamura S. Integrated total arch replacement using selective cerebral perfusion: a 6-year experience. Ann Thorac Surg. 2007;83:S805-10.

21. Kazui T, Yamashita K, Washiyama N, Terada H, Bashar AH, Suzuki K, et al. Aortic arch replacement using selective cerebral perfusion. Ann Thorac Surg. 2007; 83:S796-8; discussion S824-31.

22. Spielvogel D, Etz CD, Silovitz D, Lansman SL, Griepp RB. Aortic arch replacement with a trifurcated graft. Ann Thorac Surg. 2007;83:S791-5; discussion S824-31.

23. Ehrlich MP, McCullough J, Wolfe D, Zhang N, Shiang H, Weisz D, et al. Cerebral effects of cold reperfusion after hypothermic circulatory arrest. J Thorac Cardiovasc Surg. 2001;121:923-31. 